\title{
Esophageal Lymph Node
}

National Cancer Institute

\section{Source}

National Cancer Institute. Esophageal Lymph Node. NCI Thesaurus. Code C139196.

Any lymph node located near the esophagus, including cervical, and upper, middle, and lower thoracic lymph nodes. 